\title{
Microbial and Physicochemical Qualities of River Owena Sediments
}

\author{
Ayo O. $\mathrm{E}^{1}$, Arotupin D. $\mathrm{J}^{2}$ \\ ${ }^{1}$ Department of Biological Sciences, Joseph Ayo Babalola University Ikeji-Arakeji, Osun State, Nigeria \\ ${ }^{2}$ Department of Microbiology Federal University of Technology Akure, FUTA.
}

\begin{abstract}
Microbial quality, physicochemical parameters and heavy metals determination of sediment samples from River Owena, Oriade local government area, Owena, Nigeria. For period of dry and wet seasons. The $\mathrm{pH}$ of the sediment samples ranged from 6.44 to $8.00 \pm 0.01$, organic matter ranged from 17.15 to $35.31 \%$; water holding capacity ranged from 0.323 to $1.779 \pm 0.01 \mathrm{ml} / \mathrm{g}$; composition of sand: clay: silt were $75: 12: 13 \%$, 33:17:50 $\%, 62: 18: 20 \%$ and 50:20:30 \%; 82:2:16 \%, 48:22:30\%, 32:25:43 \% and 43:27:30 \% wet and dry seasons respectively indicated more of loamy sand, clay loam, silt clay and loam. Mean concentrations of heavy metals measured in the sediment samples included iron, zinc, manganese, lead, chromium, cadmium, nickel and copper, iron had highest values of 1.89 to $4.1 \pm 0.01 \mathrm{mg} / \mathrm{kg}$ and cadmium lowest values of 0.01 to $0.12 \pm 0.01 \mathrm{mg} / \mathrm{kg}$. A total of fifteen bacterial species were isolated from River Owena sediments, which included Escherichia coli, Enterobacter aerogenes, Klebsiella pneumoniae, Staphylococcus aureus, Staphylococcus epidermidis, Salmonella enteritidis, Bacillus subtilis, Serratia marcescens, Shigella sonnei, Bacillus cereus, Micrococcus luteus, Micrococcus varians, Pseudomonas aeruginosa, Proteus vulgaris and Erwinia amylovora. A total of ten fungal species were isolated, which included Aspergillus niger, Aspergillus flavus, Aspergillus fumigatus, Penicillium chrysogenum, Cladosporium herbarum, Mucor mucedo, Mucor plumbeus, Fusarium oxysporum, Rhizopus stolonifer and Rhizopus oryzae. The total bacterial count of the sediment ranged from $4.1 \times 10^{3}$ to $3.02 \times 10^{3} \mathrm{cfu} / \mathrm{g}$ while the total fungal count of the sediment ranged from $4 \times 10^{3}$ to $7.6 \times 10^{3} \mathrm{cfu} / \mathrm{g}$. However, the pollution level due to the presence of some pathogenic microorganisms which are of public health significance, but it could be improved upon with appropriate treatment and sanitation.
\end{abstract}

Keywords - Microbial, Physicochemical, Heavy metals, Sediment, Wet and Dry season, Health.

\section{INTRODUCTION}

Sediment is any material that settles to the bottom of a lake, river or ocean and are composed of dead and living organisms, dust from the air, soil eroded from the continents and chemical solids as well as water and nutrients (Alexopolous, 1983, Carla,1997, Robert and Stanley, 2000). Sediments differ from soil but they both provide environments for microorganisms and play different roles in the ecosystem of a wetland. Sediments near urban areas commonly contain high levels of contaminants (Lamberson et al., 1992; Cook and Wells, 1996). This constitutes a major environmental problem faced by many human impacted aquatic environments (Magalhaes et al., 2007).

The contamination of sediments with heavy metals leads to serious environmental problem (Loizidou et al., 1992). Today there is trace contamination not only of surface water but also river sediments, which are susceptible to leaching from waste dumps, mine tailings and industrial production sites (Moore et al., 1998). Organic manure, municipal waste and some fungicides often contain fairly high concentration of heavy metals. Soils receiving repeated applications of organic manures, fungicides and pesticides have exhibited high concentration of extractable heavy metals, thereby increase their concentration in runoff (Moore et al., 1998), The composition of sediments is dependent on natural factors (geological, topographical, meteorological, hydrological and biological) in the drainage basin and varies with seasonal difference in runoff volumes, weather conditions and water levels. Importantly, sediments can also be contaminated by naturally occurring sources (Muller, 2001).Heavy metals may adsorb onto sediments or be accumulated by the benthic organisms; their bioavailability and toxicity depend upon the various forms and amount bound to the sediment matrices (Chukwujindu et al., 2007). Additionally, pollutants released to surface water from industrial and municipal discharges, atmospheric deposition and run off from agricultural, urban and mining areas accumulate to harmful levels in sediments (Chukwujindu et al., 2007). 
The soil $\mathrm{pH}$, organic content and water are the main factors affecting the bacterial and fungal population and diversity. The organic carbon, nitrogen, phosphorus, potassium are important for fungi. In the absence of any of these the growth and sporulation of moulds as well as other microorganisms are hampered a lot. It has been reported that the density of fungal population occurred during the monsoon (rainy) season when the soil moisture was significantly high. Also environmental factors such as $\mathrm{pH}$, moisture, temperature, organic carbon, organic nitrogen play an important role in the distribution of mycoflora (Muller, 2001).

Soil texture can have a profound effect on many other properties and is considered among the most important physical properties. Texture is the proportion of three mineral particles, sand, silt and clay, in a soil. These particles are distinguished by size, and make up the fine mineral fraction. Particles over- $2 \mathrm{~mm}$ in diameter (Olaitan and Lombin 1984).

River Owena is a good source of domestic water to Owena people, during collection of water from this river, sediments sometimes get into the water. Therefore there is need to study the level of pollution by determining the microbial and physicochemical qualities of sediments because of its potential health hazard.

\section{MATERIALS AND METHODS}

\section{The study area}

River Owena is located about four kilometers from Joseph Ayobabalola University Ikeji Arakeji along Ilesha-Akure express way in Oriade local government area of Osun State, Nigeria on latitude N 7.403135 and longitude E 5.014589. It is a fresh water and free-flowing during raining season but slow-moving at the onset of dry season.

\section{Study design}

The analysis cover a period of six months, from July 2015 to January 2016 covering wet and dry season, sediment samples were collected at four sampling points (two each at both side of the bridge). The human activities around the river and the sampling points were evaluated and noted on monthly basis.

\section{Sampling points}

The four sampling points along the longitudinal course of River Owena (Figure 2), were river water flowing across the right-side of the bridge along Akure-Ilesha express-way at $\mathrm{N} 7^{\circ} 24^{\prime} 11^{\prime \prime} \mathrm{E} 5^{\circ} 0^{\prime} 52^{\prime \prime}$, this point was about $64 \mathrm{~cm}$ deep (point One); Two- This point was across the river about one hundred metres away from sampling point One, It is about one hundred and thirty metres from the palm plantation at $\mathrm{N}$ $7^{\circ} 24^{\prime} 1^{\prime \prime}$ E $5^{\circ} 0^{\prime} 49^{\prime \prime}$, this point was about $80 \mathrm{~cm}$ deep; Three- This point was one hundred and fifty metres away from sampling point two. It was close to the farmland along the bank of the river at $\mathrm{N} 724^{\prime} 12^{\prime \prime}$ E $5^{\circ} 0^{\prime} 48^{\prime \prime}$, this point was about $50 \mathrm{~cm}$ deep; and four- This point was one hundred metres away from sampling point three at $\mathrm{N} 7^{\circ} 24^{\prime}$ $12^{\prime \prime}$ E $5^{\circ} 0^{\prime} 46^{\prime \prime}$, this point which was about $90 \mathrm{~cm}$ deep used to be the site where domestic water was collected. Water from this river is still collected for domestic purposes at the peak of dry season especially by the people living near and close to the river. Prior to this study, water from sampling point four was used for domestic purposes. Human activities on the river recently before the conclusion of this research included use of the water for cement blockmoulding, car wash, commercial water supply to people, along the bank of the river are farms with crops such as maize, sugar cane and vegetables such as spinach and pepper plantation. The river also serves as recreational swimming pool for small children from nearby primary and secondary schools. Various types of birds and egrets were seen on the river.

\section{Sample collection}

Sediment samples were collected during wet and dry season from the four points. Sterile bottles of $500 \mathrm{ml}$ were used for sample collection. Samples for microbial analysis were collected aseptically, labeled and stored in ice packed plastic coolers and transported to the laboratory where analysis within 24 hours of collection was carried out (Dubey and Maheshwari, 2004). 


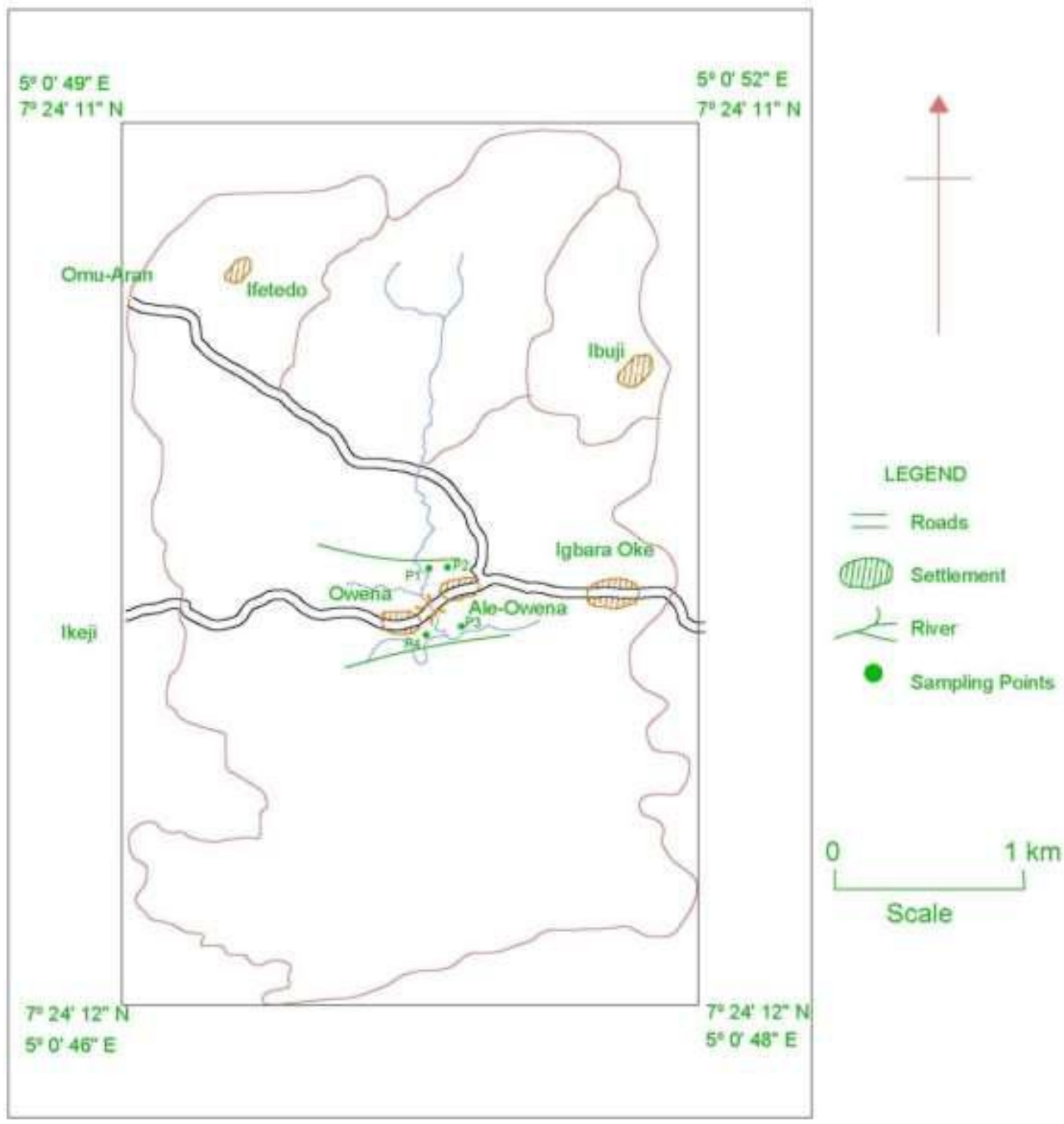

Fig.1: Map of River Owena sampling sites

\section{Isolation of fungi from sediment samples}

Pour plate method was used to isolate fungi associated with the sediment samples and the plates were incubated at $25^{\circ} \mathrm{C}$ for 48-72 hours for growth. The fungal counts were determined according to the methods of (Olayemi, 1990; APHA, 2002; Dubey and Maheshwari, 2004).

\section{Purification, characterization and identification of} fungal isolates

Pure cultures were obtained by sub-culturing different and distinct colonies onto sterile sabouraud dextrose agar plates containing $1 \%$ streptomycin. The fungal isolates were incubated and examined macroscopically and microscopically using lacto-phenol cotton blue to determine their colonial and morphological characteristics respectively. The isolates were identified according to the keys of Onions et al. (1981), Alabi (1994), Fawole and Oso (2001) and Dubey and Maheshwari (2004).

Isolation of bacteria from sediment samples

Pour plate method was used to isolate bacteria from sediment samples, during which the plates were incubated at $37^{\circ} \mathrm{C}$ for $24-48$ hours. The bacterial counts were determined according to the methods of (Olayemi, 1990; APHA, 2002; Dubey and Maheshwari, 2004). 


\section{Purification, characterization and identification of} bacterial isolates

Pure cultures were obtained by streaking different and distinct colonies onto sterile nutrient agar plates. The pure cultures obtained were then transferred onto agar slants in McCartney bottles and incubated at $37^{\circ} \mathrm{C}$ for 24 hours. The characterization and identification of bacterial isolates were based on the colonial morphology and biochemical tests carried out on pure culture of the isolates (Buchanan and Gibbons, 1974; Fawole and Oso, 2001; Dubey and Maheshwari, 2004; Garrity et al., 2004).

\section{Trace and heavy metals}

Trace and heavy metals determination was carried out using standard of Ravera et al. (2003) and Aiyesanmi (2006). This technique permits the measurement of a series of elements at the same time, the sediments were analyzed for zinc, manganese, cadmium, lead and iron, chromium, copper, nickel and their concentrations.

\section{Determination of physicochemical characteristics of River Owena sediments}

The $\mathrm{pH}$, organic matter content and water holding capacity were determined using the method of Pramer and Schmidt (1984). Determination of sediments texture was done using the method of Awolumate, (1977); Olaitan and Lombin, (1984). Appropriate textural classification was then referred to get the soil texture.

\section{Statistical analysis}

All the data obtained in this study were subjected to analysis of variance (ANOVA) Followed by Duncans New multiple range test was used to separate means using SPSS
11.09 for windows and significance level was set at $p<0.05$ (Norusis, 2006).

\section{RESULTS AND DISCUSSION}

The $\mathrm{pH}$, total alkalinity, organic matter content, nitrate and phosphate of the sediment samples ranged from 6.44 to 7.00 $\pm 0.01,19.40$ to $138.16 \pm 0.01 \mathrm{mg} / \mathrm{l} \mathrm{CaCo} 3$, (\% dry wt) 17.16 to $20.04 \%, \quad 0.42$ to $1.03 \pm 0.01 \mathrm{mg} / \mathrm{kg}$, and 28.87 to $30.00 \pm 0.01 \mathrm{mg} / \mathrm{kg}$ respectively during wet season (Table 1 ). While $\mathrm{pH}$, total alkalinity, organic matter content, nitrate and phosphate ranged from 6.98 to $8.00 \pm 0.01,119.40$ to $138.16 \pm 0.01 \mathrm{mg} / \mathrm{l} \mathrm{CaCo}$, (\% dry wt) 27.26 to $35.32 \%, 1.55$ to $2.30 \pm 0.01 \mathrm{mg} / \mathrm{kg}, 0.40$ to $1.30 \pm 0.01 \mathrm{mg} / \mathrm{kg}$ respectively during dry season (Table 2).The $\mathrm{pH}$ of the sediments was slightly acidic during wet season and slightly alkaline during dry season which could be as a result of seasonal variation. This is similar to the results obtained by Tamaki et al.(2005) and Ekeanyanwu et al.(2010)with a pH of 6.4, that variation in $\mathrm{pH}$ depend on the season of the year.The total alkalinity, and phosphate values of the soil sediment were higher during dry season compare to wet season, while nitrate values was higher during wet season compare to dry season. Discharge and subsequent sedimentation of suspended particulates from phosphate and nitrogen fertilizers, and domestic wastes discharged into the river as a result of rainfall might have also contributed to the increase in sediment nitrate and phosphate contents. The findings in this study were consistent with those reported by (Tukura et al., 2005) and (Ekeanyanwu et al., 2010).

Table.1: Physicochemical properties of River Owena sediment (wet season)

\begin{tabular}{lccccc}
\hline Parameters & \multicolumn{2}{c}{ P1 } & P2 & P3 & P4 \\
& & & & & \\
\hline pH & $6.76 \pm 0.01^{\mathrm{c}}$ & $7.01 \pm 0.01^{\mathrm{d}}$ & $6.67 \pm 0.01^{\mathrm{b}}$ & $6.45 \pm 0.01^{\mathrm{a}}$ & \\
P.Alkal. $\left(\mathrm{mg} / \mathrm{L} \mathrm{CaCo}_{3}\right)$ & $0.00 \pm 0.00$ & $0.00 \pm 0.00$ & $0.00 \pm 0.00$ & $0.00 \pm 0.00$ & \\
T.Alkal. $\left(\mathrm{mg} / \mathrm{L} \mathrm{CaCo}_{3}\right)$ & $73.81 \pm 0.01^{\mathrm{c}}$ & $80.21 \pm 0.01^{\mathrm{d}}$ & $67.42 \pm 0.01^{\mathrm{b}}$ & $63.35 \pm 0.01^{\mathrm{a}}$ & \\
$\mathrm{NO}_{3}{ }^{-}(\mathrm{mg} / \mathrm{kg})$ & $2.02 \pm 0.01^{\mathrm{a}}$ & $2.95 \pm 0.01^{\mathrm{d}}$ & $2.66 \pm 0.01^{\mathrm{c}}$ & $2.42 \pm 0.01^{\mathrm{b}}$ & \\
$\mathrm{PO}_{4^{3-}}(\mathrm{mg} / \mathrm{kg})$ & $0.21 \pm 0.01^{\mathrm{b}}$ & $0.41 \pm 0.01^{\mathrm{c}}$ & $0.10 \pm 0.01^{\mathrm{a}}$ & $0.86 \pm 0.01^{\mathrm{d}}$ & \\
Organic matter $(\%)$ & $17.15 \pm 0.01^{\mathrm{a}}$ & $19.35 \pm 0.01^{\mathrm{c}}$ & $20.03 \pm 0.01^{\mathrm{d}}$ & $17.76 \pm 0.01^{\mathrm{b}}$ & \\
\hline
\end{tabular}

*Data are presented as Mean \pm S.E $(n=3)$. Values in the same row followed by the same superscript letters are not significantly different using Duncan's multiple range test at $\mathrm{p}<0.05$

Table.2: Physicochemical properties of River Owena sediment (dry season)

\begin{tabular}{llllll}
\hline Parameters & P1 & \multicolumn{1}{c}{ P2 } & P3 & P4 \\
\hline pH & $8.01 \pm 0.01^{\mathrm{d}}$ & $7.67 \pm 0.01^{\mathrm{b}}$ & $7.71 \pm 0.01^{\mathrm{c}}$ & $6.97 \pm 0.01^{\mathrm{a}}$ & \\
P.Alkal. $\left(\mathrm{mg} / \mathrm{L} \mathrm{CaCo}_{3}\right)$ & $0.00 \pm 0.00$ & $0.00 \pm 0.00$ & $0.00 \pm 0.00$ & $0.00 \pm 0.00$ &
\end{tabular}




\begin{tabular}{llllr}
\hline T.Alkal. $\left(\mathrm{mg} / \mathrm{LCaCo}_{3}\right)$ & $119.14 \pm 0.01^{\mathrm{b}}$ & $138.16 \pm 0.01^{\mathrm{d}}$ & $122.31 \pm 0.01^{\mathrm{c}}$ & $113.01 \pm 0.01^{\mathrm{a}}$ \\
$\mathrm{NO}_{3}{ }^{-}(\mathrm{mg} / \mathrm{kg})$ & $1.87 \pm 0.01^{\mathrm{b}}$ & $2.31 \pm 0.01^{\mathrm{d}}$ & $1.98 \pm 0.01^{\mathrm{c}}$ & $1.56 \pm 0.01^{\mathrm{a}}$ \\
$\mathrm{PO}_{4}{ }^{3-}(\mathrm{mg} / \mathrm{kg})$ & $0.42 \pm 0.01^{\mathrm{a}}$ & $1.01 \pm 0.01 \mathrm{c}$ & $0.56 \pm 0.01^{\mathrm{b}}$ & $1.31 \pm 0.01^{\mathrm{d}}$ \\
Organic matter $(\%)$ & $30.31 \pm 0.0^{\mathrm{c}}$ & $27.27 \pm 0.01^{\mathrm{a}}$ & $35.31 \pm 0.01^{\mathrm{d}}$ & $28.11 \pm 0.01^{\mathrm{b}}$
\end{tabular}

*Data are presented as Mean \pm S.E $(n=3)$. Values in the same row followed by the same superscript letters are not significantly different using Duncan's multiple range test at $\mathrm{p}<0.05$

Texture and water holding capacity of River Owena sediment (wet and dry season)

The texture of the sediments of River Owena during wet season was composed of sand, clay and silt however, the percentage composition of sand to silt to clay in sediment samples points one, two, three and four was 75:12:13\%, 33:17:50 \%, 62:18:20 \% and 50:20:30 \% respectively (Figure 2). The texture of the sediments of River Owena during dry season was composed of sand, clay and silt however, the percentage composition of sand to silt to clay in sediment samples points one, two, three and four was $82: 2: 16 \%, 48: 22: 30 \%, 32: 25: 43 \%$ and $43: 27: 30 \%$ respectively (Figure 3 ). This was similar to the findings of Morgan (2010), which stated that the texture of a soil is not readily subject to change, so it is considered a basic property of a soil. The water holding capacity $(\mathrm{ml} / \mathrm{g})$ of sediment from River Owena from July 2015 to Jan. 2016 is shown in (Table 3). During wet season the values ranged from $0.323 \mathrm{ml} / \mathrm{g}$ in sample point one being lowest in September to a highest point of $0.738 \mathrm{ml} / \mathrm{g}$ in sample point two in July 2015.The water holding capacity $\mathrm{ml} / \mathrm{g}$ of the sediment during dry season ranged from $0.381 \mathrm{ml} / \mathrm{g}$ in sample point three being lowest in Nov. and $1.779 \mathrm{ml} / \mathrm{g}$ in sample point two being highest in Dec. 2015., these variation may be due to the nature of the sediment, high rate of sedimentation and decomposition of foliage and other vegetative remains in the sediment Adegunwa (2003), who obtained 0.4 to $0.2 \mathrm{ml} / \mathrm{g}$ in his research.

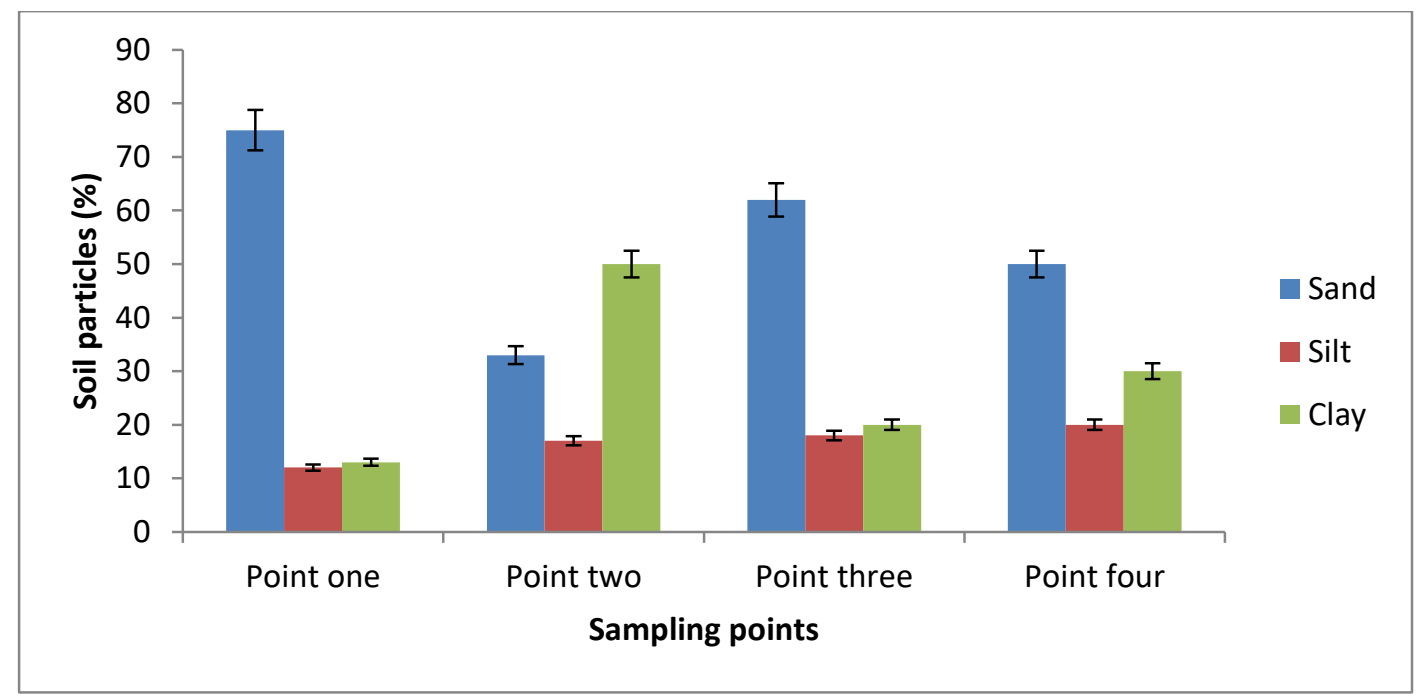

Fig.2: Wet season texture of River Owena sediments 


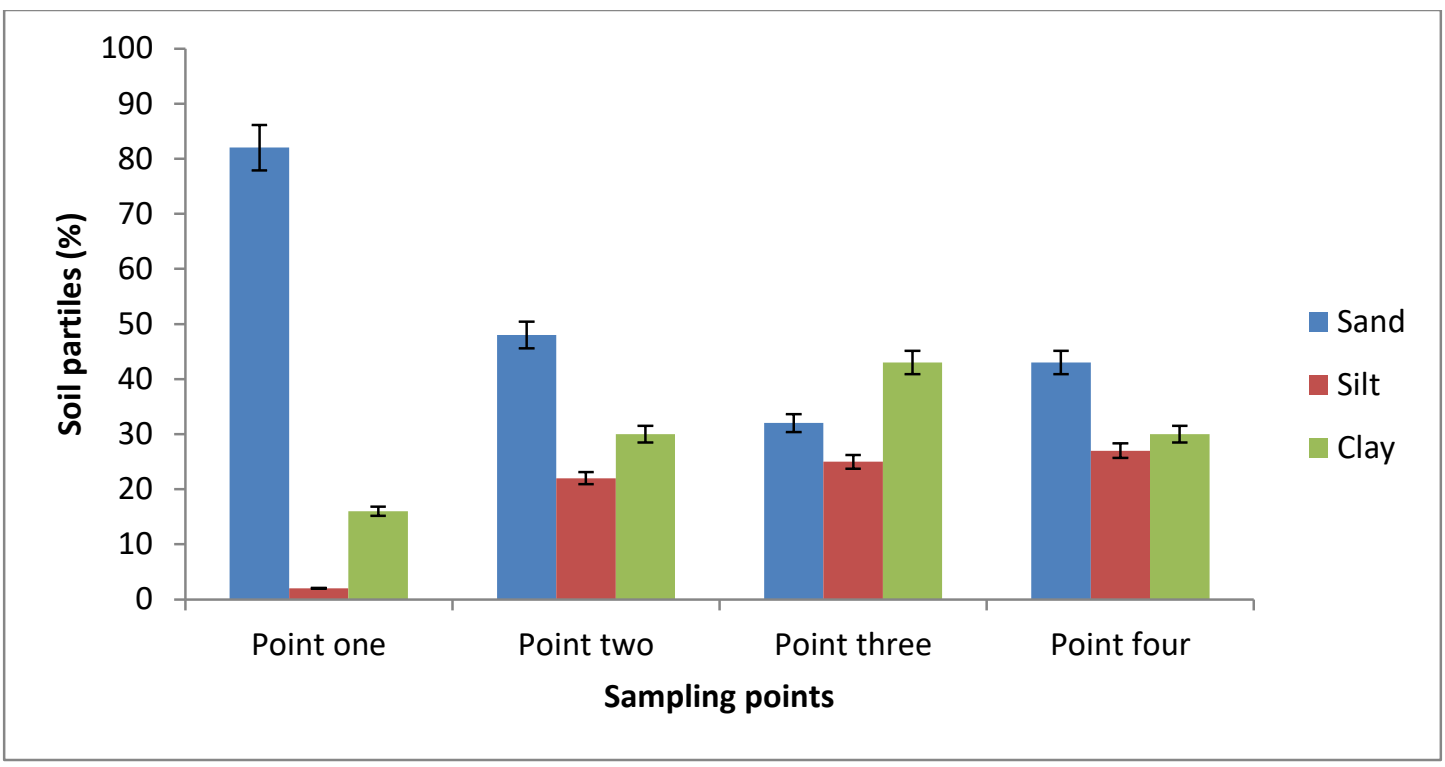

Fig.3: Dry season texture of River Owena sediments

Table.3: Water holding capacity $(\mathrm{ml} / \mathrm{g})$ of River Owena sediments

\begin{tabular}{cccccc}
\hline Months & Point One & Point Two & Point Three & Point Four \\
\multicolumn{7}{c}{} & & & \\
\hline July. 2015 & $0.387 \pm 0.01^{\mathrm{a}}$ & $0.738 \pm 0.01^{\mathrm{d}}$ & $0.386 \pm 0.01^{\mathrm{b}}$ & $0.503 \pm 0.01^{\mathrm{c}}$ & \\
Aug. 2015 & $0.354 \pm 0.01^{\mathrm{a}}$ & $0.596 \pm 0.01^{\mathrm{d}}$ & $0.548 \pm 0.01^{\mathrm{c}}$ & $0.482 \pm 0.01^{\mathrm{b}}$ & \\
Sept. 2015 & $0.323 \pm 0.01^{\mathrm{d}}$ & $0.617 \pm 0.01^{\mathrm{c}}$ & $0.497 \pm 0.01^{\mathrm{b}}$ & $0.476 \pm 0.01^{\mathrm{a}}$ & \\
Oct. 2015 & $0.700 \pm 0.01^{\mathrm{c}}$ & $0.889 \pm 0.01^{\mathrm{d}}$ & $0.383 \pm 0.01^{\mathrm{a}}$ & $0.561 \pm 0.01^{\mathrm{b}}$ & \\
Nov. 2016 & $0.722 \pm 0.01^{\mathrm{c}}$ & $0.863 \pm 0.01^{\mathrm{d}}$ & $0.381 \pm 0.01^{\mathrm{a}}$ & $0.512 \pm 0.01^{\mathrm{b}}$ & \\
Dec. 2015 & $0.960 \pm 0.01^{\mathrm{a}}$ & $1.779 \pm 0.01^{\mathrm{d}}$ & $1.415 \pm 0.01^{\mathrm{c}}$ & $1.350 \pm 0.01^{\mathrm{b}}$ & \\
Jan. 2015 & $0.989 \pm 0.01^{\mathrm{a}}$ & $1.709 \pm 0.01^{\mathrm{d}}$ & $1.333 \pm 0.01^{\mathrm{c}}$ & $1.305 \pm 0.01^{\mathrm{b}}$ & \\
\hline
\end{tabular}

*Data are presented as Mean \pm S.E $(n=3)$. Values in the same row followed by the same superscript letters are not significantly different using Duncan's multiple range test at $\mathrm{p}<0.05$

\section{Heavy metals of River Owena sediments (dry and wet} season)

The mean concentrations of heavy metals $(\mathrm{mg} / \mathrm{kg})$ of sediments samples determined during wet season indicated iron has the highest values ranged from 1.89 to $3.00 \pm 0.01$ $\mathrm{mg} / \mathrm{kg}$, while cadmium had the least values of 0.01 to $0.04 \pm 0.01 \mathrm{mg} / \mathrm{kg}$ (Figure 4). Similarly during dry season iron had the highest values ranged from 2.38 to $4.10 \pm 0.01$ $\mathrm{mg} / \mathrm{kg}$ while, cadmium had the least values of 0.04 to $0.12 \pm 0.01 \mathrm{mg} / \mathrm{kg}$ (Figure 5). This result is similar to the one obtained by Dosumu et al. (2003); Ravera et al. (2003) and Adefemi and Awokunmi (2010), they stated that increase of heavy metals could be due to the precipitation of these elements in this aquatic environment. 


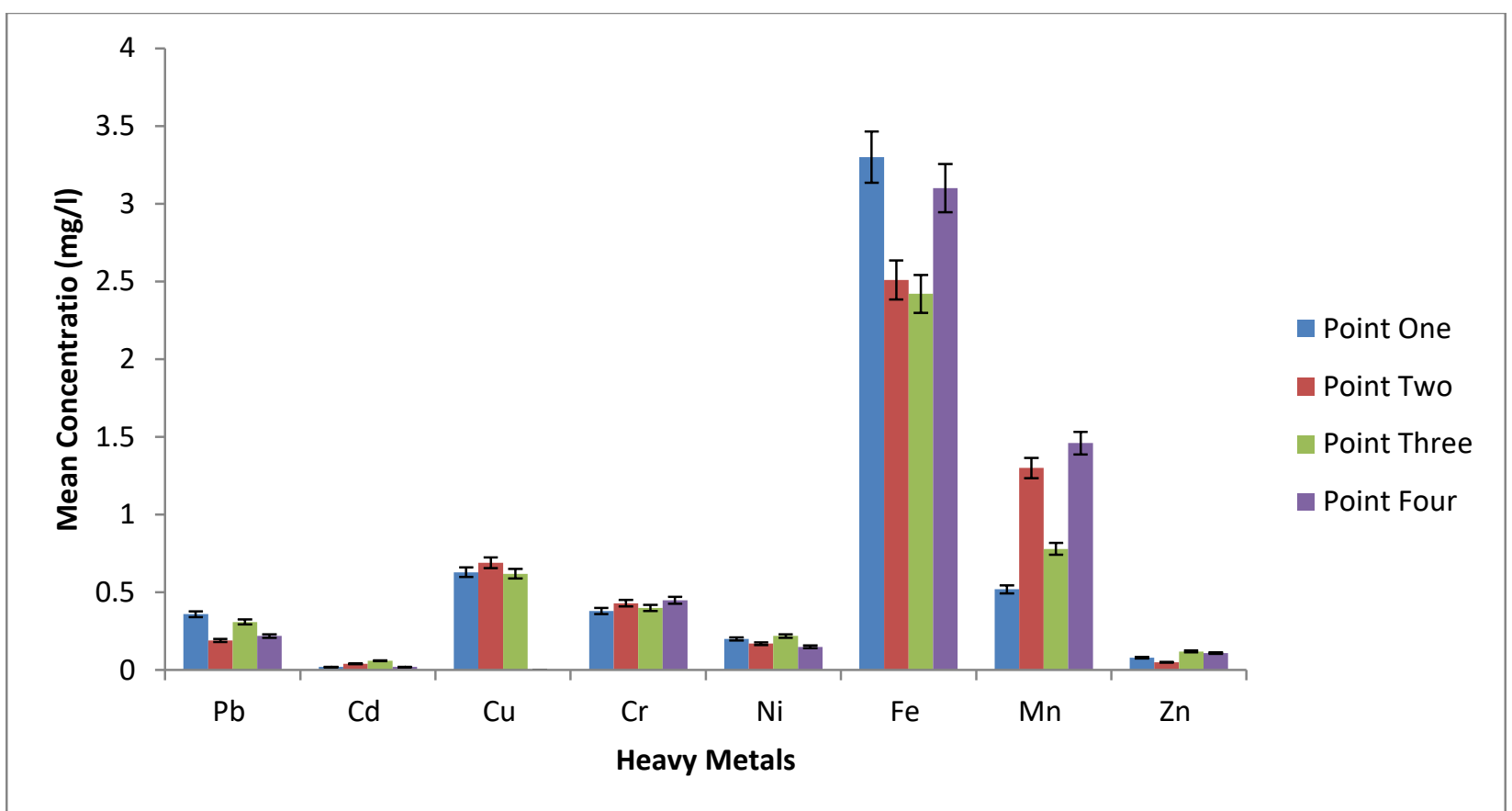

Fig.4: Wet season mean concentration of heavy metals from River Owena sediments

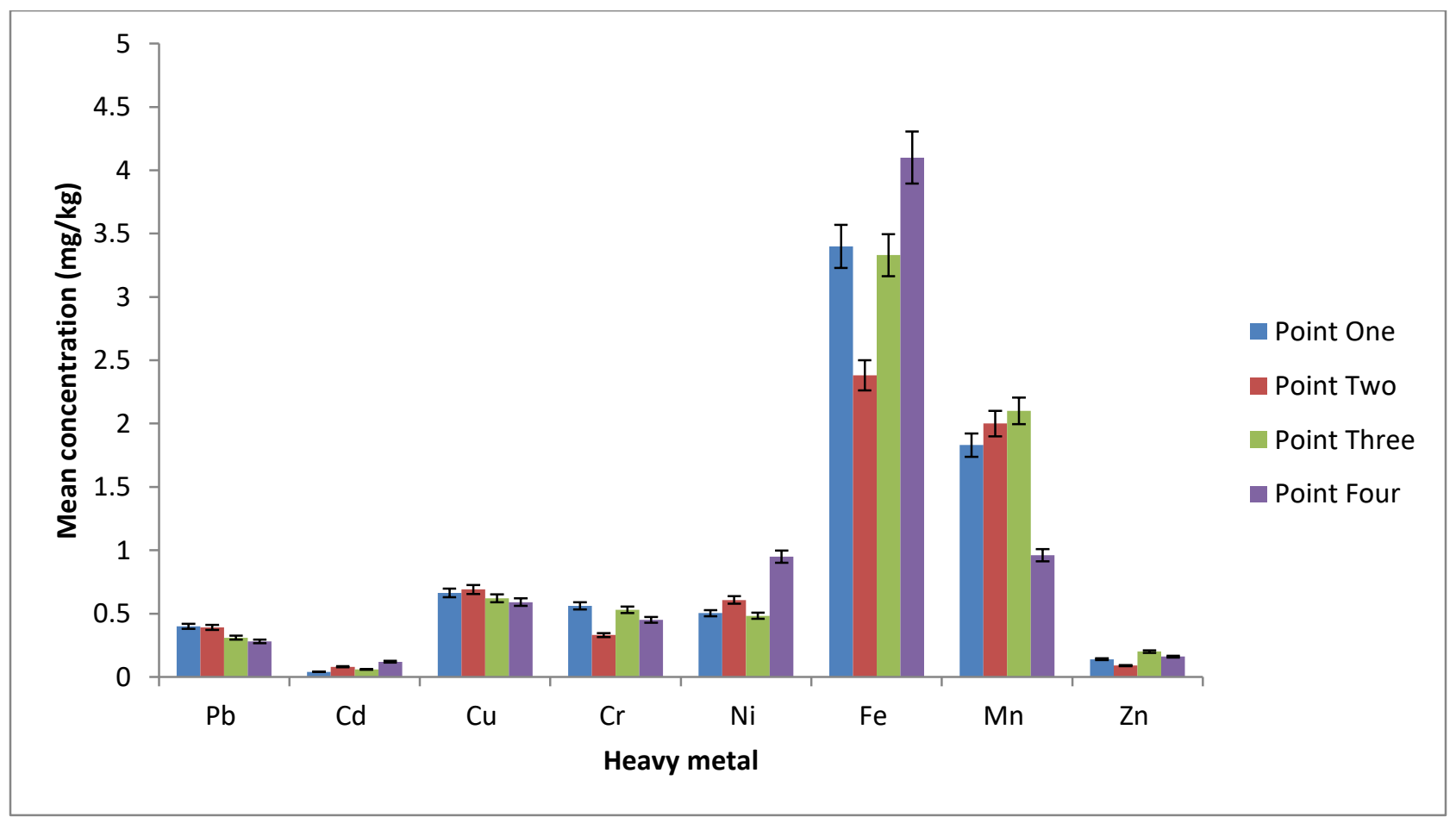

Fig.5: Dry season mean concentration of heavy metals from River Owena sediment

The total bacterial counts (cfu/g) of River Owena sediments

The total bacterial counts for the four samples points of sediments determined from July 2015 to Jan. 2016 covering (wet and dry seasons) ranged from $4.1 \times 10^{3}$ to $3.02 \mathrm{x}$
$10^{3} \pm 0.01 \mathrm{cfu} / \mathrm{g} \quad$ (Table 4). The lowest count occurred in sample point two in August, 2015, while, the highest count occurred in sample point one in July, 2015. Wet season recorded a range of $3.02 \times 10^{3} \mathrm{cfu} / \mathrm{g}$ in July, 2015 to $4.1 \mathrm{x}$ $10^{3} \pm 0.01 \mathrm{cfu} / \mathrm{g}$ in August, 2015, but dry season had a range 
of $1.23 \times 10^{3} \pm 0.01 \mathrm{cfu} / \mathrm{g}$ in Nov., 2015 to $3.0 \times 10^{3} \pm 0.01$ $\mathrm{cfu} / \mathrm{g}$ in December. Total bacterial counts of the four samples points of sediments determined illustrated that wet season had higher count compared to dry season. Sediment is novel in the sense that the organism is found in fecal contaminated water and its presence in sediment too is reported by few researchers. Erah et al. (2011) in their study of quality of underground water in Benin found Escherichia coli and Streptococcus faecalis to be the major contaminants at abnormal levels.

Table.4: Total bacterial counts of River Owena sediments

\begin{tabular}{lllll}
\hline Months & \multicolumn{2}{c}{ Point One } & Point Two & Point Three \\
& & & & \\
\hline July.2015 & $3.02 \times 10^{3} \pm 0.01^{\mathrm{d}}$ & $1.51 \times 10^{3} \pm 0.01^{\mathrm{c}}$ & $6.4 \times 10^{3} \pm 0.01^{\mathrm{a}}$ & $7.6 \times 10^{3} \pm 0.01^{\mathrm{b}}$ \\
Aug. 2015 & $5.5 \times 10^{3} \pm 0.01^{\mathrm{b}}$ & $4.1 \times 10^{3} \pm 0.01^{\mathrm{a}}$ & $7.5 \times 10^{3} \pm 0.01^{\mathrm{c}}$ & $5.5 \times 10^{3} \pm 0.01$ \\
Sept. 2015 & $5.0 \times 10^{3} \pm 0.01^{\mathrm{a}}$ & $5.1 \times 10^{3} \pm 0.01^{\mathrm{b}}$ & $6.7 \times 10^{3} \pm 0.01^{\mathrm{d}}$ & $6.2 \times 10^{3} \pm 0.01^{\mathrm{c}}$ \\
Oct. 2015 & $1.10 \times 10^{3} \pm 0.01^{\mathrm{c}}$ & $6.3 \times 10^{3} \pm 0.01^{\mathrm{a}}$ & $8.6 \times 10^{3} \pm 0.01^{\mathrm{b}}$ & $1.20 \times 10^{3} \pm 0.01^{\mathrm{d}}$ \\
Nov. 2015 & $1.23 \times 10^{3} \pm 0.01^{\mathrm{d}}$ & $9.9 \times 10^{3} \pm 0.01^{\mathrm{b}}$ & $9.1 \times 10^{3} \pm 0.01^{\mathrm{a}}$ & $9.9 \times 10^{3} \pm 0.01^{\mathrm{b}}$ \\
Dec. 2015 & $4.3 \times 10^{3} \pm 0.01^{\mathrm{c}}$ & $3.7 \times 10^{3} \pm 0.01^{\mathrm{b}}$ & $6.2 \times 10^{3} \pm 0.01^{\mathrm{d}}$ & $3.0 \times 10^{3} \pm 0.01^{\mathrm{a}}$ \\
Jan. 2016 & $5.8 \times 10^{3} \pm 0.01^{\mathrm{b}}$ & $6.2 \times 10^{3} \pm 0.01^{\mathrm{c}}$ & $6.2 \times 10^{3} \pm 0.01^{\mathrm{c}}$ & $3.8 \times 10^{3} \pm 0.01^{\mathrm{a}}$ \\
\hline
\end{tabular}

*Data are presented as Mean \pm S.E $(n=3)$. Values in the same row followed by the same superscript letters are not significantly different using Duncan's multiple range test at $\mathrm{p}<0.05$

\section{Bacterial isolates of River Owena sediments}

A total of fifteen bacterial species were isolated from sediments which included Escherichia coli, Enterobacter aerogenes, Klebsiella pneumoniae, Staphylococcu saureus, S. epidermidis, Salmonella enteritidis, Bacillus subtilis, Serratia marcescens, Shigella sonnei, Bacillus cereus , Micrococcus luteus, Micrococcus varians, Pseudomonas aeruginosa, P. vulgaris and Erwinia amylovora (Table 5). The frequencies of occurrence of bacterial isolates ranged from $1.8-15.0 \%$ in sediments from River Owena Enterobacter aerogenes occurred most frequently (15\%), while $M$. luteus, B. subtilis, Proteus vulgaris, occurred least (1.8\%).The finding was similar to that of Adegunwa (2003) in Oyun River, Ishii et al., (2006) and Erah et al., (2011).

Table.5: Bacterial frequency distribution of River Owena sediments

\begin{tabular}{lc}
\hline Isolates & \% Frequency of Occurrence \\
\hline Escherichia coli & 14.0 \\
Enterobacter aerogenes & 15.0 \\
Klebsiella pneumoniae & 4.8 \\
Staphylococcus aureus & 5.7 \\
Micrococcus luteus & 1.8 \\
M. varians & 8.5 \\
Pseudomonas aeruginosa & 5.8 \\
Bacillus subtilis & 1.8 \\
Salmonella enteritidis & 8.4 \\
Proteus vulgaris & 1.8 \\
S. epidermidis & 9.3 \\
Erwinia amylovora & 3.8 \\
B. cereus & 6.7 \\
Shigella sonnei & 6.3 \\
Serratia marcescens & 6.3 \\
& Total 100 \\
\hline
\end{tabular}

Values represents means \pm Standard error of means. 
Total fungal counts (sfu/g) of River Owena sediments

Total fungal counts for the four samples points of sediments determined from July 2015 to Jan. 2016 covering (wet and dry seasons) ranged from $4 \times 10^{3}$ to $7.6 \times 10^{3} \pm 0.01 \mathrm{sfu} / \mathrm{g}$ (Table 6). The lowest count occurred in sample point four in Dec., 2015. While, the highest count occurred in sample point one in Aug., 2015.Wet season had a range of $2.3 \mathrm{x}$ $10^{3} \pm 0.01 \mathrm{sfu} / \mathrm{g}$ in Sept., 2015 to $7.6 \times 10^{3} \pm 0.01 \mathrm{sfu} / \mathrm{g}$ in Aug., 2015. Dry season had a range of $4 \times 10^{3} \pm 0.01 \mathrm{sfu} / \mathrm{g}$ in Dec., 2015 to $4.9 \times 10^{3} \pm 0.01 \mathrm{sfu} / \mathrm{g}$ in Nov. This result is similar to the result obtained by Alabi, (1994).

Table.6: Total fungal counts of River Owena sediments

\begin{tabular}{lllll}
\hline Months & Point One & Point Two & Point Three & Point Four
\end{tabular}

\begin{tabular}{lllll}
\hline July. 2015 & $3.3 \times 10^{3} \pm 0.01^{\mathrm{c}}$ & $7.1 \times 10^{3} \pm 0.01^{\mathrm{d}}$ & $3.2 \times 10^{3} \pm 0.01^{\mathrm{a}}$ & $4.3 \times 10^{3} \pm 0.01^{\mathrm{b}}$ \\
Aug. 2015 & $7.6 \times 10^{3} \pm 0.01^{\mathrm{d}}$ & $5.1 \times 10^{3} \pm 0.01^{\mathrm{c}}$ & $2.9 \times 10^{3} \pm 0.01^{\mathrm{a}}$ & $5.0 \times 10^{3} \pm 0.01^{\mathrm{b}}$ \\
Sept. 2015 & $2.3 \times 10^{3} \pm 0.01^{\mathrm{a}}$ & $2.8 \times 10^{3} \pm 0.01^{\mathrm{b}}$ & $3.0 \times 10^{3} \pm 0.01^{\mathrm{c}}$ & $6.5 \times 10^{3} \pm 0.01^{\mathrm{d}}$ \\
Oct. 2015 & $4.6 \times 10^{3} \pm 0.01^{\mathrm{b}}$ & $5.3 \times 10^{3} \pm 0.01^{\mathrm{c}}$ & $3.7 \times 10^{3} \pm 0.01^{\mathrm{a}}$ & $5.3 \times 10^{3} \pm 0.01^{\mathrm{c}}$ \\
Nov.2015 & $3.2 \times 10^{3} \pm 0.01^{\mathrm{a}}$ & $3.9 \times 10^{3} \pm 0.01^{\mathrm{b}}$ & $4.9 \times 10^{3} \pm 0.01^{\mathrm{d}}$ & $4.4 \times 10^{3} \pm 0.01^{\mathrm{c}}$ \\
Dec.2015 & $6 \times 10^{3} \pm 0.01^{\mathrm{b}}$ & $1.0 \times 10^{3} \pm 0.01^{\mathrm{d}}$ & $7 \times 10^{3} \pm 0.01^{\mathrm{c}}$ & $4 \times 10^{3} \pm 0.01^{\mathrm{a}}$ \\
Jan. 2016 & $2.7 \times 10^{3} \pm 0.01^{\mathrm{b}}$ & $4.0 \times 10^{3} \pm 0.01^{\mathrm{d}}$ & $2.3 \times 10^{3} \pm 0.01^{\mathrm{a}}$ & $3.0 \times 10^{3} \pm 0.01^{\mathrm{c}}$
\end{tabular}

*Data are presented as Mean \pm S.E $(n=3)$. Values in the same row followed by the same superscript letters are not significantly different using Duncan's multiple range test at $\mathrm{p}<0.05$

\section{Fungal isolates of River Owena sediments}

The ten fungal species isolated from the sediments included Aspergillus niger, A. flavus, A. fumigatus, Penicillium chrysogenum, Cladosporium herbarum, Mucor mucedo, $M$. plumbeus, Fusarium oxysporum, Rhizopus stolonifer and Rhizopus oryzae (Table 7). Aspergillus niger was the most frequently isolated fungus occurring in all the samples, with a frequency of occurrence of $22.2 \%$ and Penicillium chrysogenum occurred less abundantly in the samples which is similar to those obtained by Alabi, (1994)in a similar study on Oyun River and Akpata and Ekundayo, (1983).

Table.7: Fungal frequency distribution of River Owena sediments

\begin{tabular}{lc} 
I s o l a t e s & F r e q u e c y o f O c c u r r e n c e \\
\hline Aspergillus niger & 22.2 \\
Cladosporium herbarum & 7.8 \\
A. flavus & 12.5 \\
Mucor mucedo & 4.4 \\
A. fumigatus & 10.5 \\
Fusarium oxysporum & 6.5 \\
M. plumbeus & 12.5 \\
Penicillium chrysogenum & 3.4 \\
Rhizopus stolonifer & 10.7 \\
R. oryzae & 9.5 \\
& Total 100 \\
\hline
\end{tabular}

Values represents means \pm Standard error of means

Fungi and bacteria are part of the group of living organisms found in sediments, they may be found in the surface of decaying plant or animals materials in river. Human activities such as farming, swimming, grazing of animals and car wash park in and around the river bank which will increase the contamination level along-side run-offs should be reduced or totally discouraged. 


\section{REFERENCES}

[1] Adefemi, S. O. and Awokunmi, E. E. (2010). Determination of physicochemical parameters and

[2] Adegunwa, A. (2003). Microorganisms in Sediments of River Oyun and a Pond (B.Sc. Project, Department of Microbiology, University of Ilorin, Ilorin, Nigeria.): pp. 1-14.

[3] Aiyesanmi, A. F. (2006). "Baseline Concentration of Heavy Metals in Water Samples from Rivers Within Okitipupa South- east Belt of the Nigerian Bitumen Field," Journal of Chemical Society of Nigeria, 31(12): 30-37.

[4] Alabi,R.O. (1994). Some Lower Aquatic Phycomycetes from River Oyun. Centre Point,4(1): 114.

[5] Alexopoulos, C. J. (1983). Introductory Mycology. John Wiley \& Sons Inc. New York, London.pp. 100214.

[6] APHA, (2002). Standard methods for the examination of water and waste Water. 20th Edition. American Public Health Association, Washington. pp. 201-132.

[7] Awolumate, O. (1977). Selected methods for soil and plant analysis. Central Analytical Laboratories. Cocoa Research Institute of Nigeria, pp. 58-60.

[8] Bucchanan, R.E. and Gibbons, N.E. (1974). Bergey's Manual ofDeterminative Bacteriology. 8th edition.William and Wilkins Co., Baltimore. pp. 189.

[9] Carla, W. M. (1997). Fundamentals of Geology. Third Edition. W. M. C. Brown Publishers, U.K. pp. 339.

[10] Chukwujindu, M.A., Godwin, E.N. and Francis, O.A. (2007). Assessment of contamination by heavy metals in sediments of Ase-River, Niger Delta, Nigeria. Research Journal of Environmental Science,109(1): $220-228$.

[11] Cook, N.H. and Wells, P.G.(1996). Toxicity of Halifax harbor sediments: an evaluation of Microtox Solid Phase test. Water Quality Resources, 31(4): 673-708.

[12] Dosumu, O. O., Salami, N. and Adekola, F. A. (2003). Comparative Study of Trace Element Levels in Some Local Vegetable Varieties and Irrigation Waters from Different Locations in Ilorin, Nigeria. Bulletin of Chemical Society ofEthiopia, 17(1):1-6.

[13] Dubey, R.C. and Maheshwari, D.K. (2004). Practical Microbiology. S. Chad and Company, New Delhi. pp. 162- 301

[14]Ekeanyanwu, R., Ogbuniyi, C. A. and Elienajirhevwe, O. F. (2010). Trace metals distribution in fish tissue, bottom sediments and water from Okemeshi river in heavy metals in water samples from Itaogbolu area of Ondo State, Nigeria. African Journal of Environmental Science and Technology,4(3): 145- 148. Delta State, Nigeria. Environmental Resources,5: 610.

[15] Ishii, S., Ksoll, W. B., Hicks, R. E. and Sadowsky, M.J. (2006). Presence and Growth of Naturalized Escherichia coli in Temperate Soils from Lake Superior Watersheds. Applied and Environmental Microbiology,72(1): 612-621.

[16] Lamberson, J.O., Dewitt, T.H. and Swartz, R.C. (1992). Assessment ofsediment toxicity to marine benthos. In: Buron, G.S (Edition): Sediment toxicity Assessment, Lewis Publication Boca raton, FL, pp.183-211

[17]Loizidou, M., Haralambous, K.J. and Sakellarides, P.O. (1992). Environmental study of the marinas Part II. A study on the removal of metals from theMarianas sediment. EnvironmentalTechnology, 3: 245-252.

[18] Magalhaes, C., Coasta, J., Teixeira, C. and Bordalo, A.A. (2007). Impacts of trace Metals on denitrification in estuarine sediments of the Douro Riverestuary, Portugal. Marine Chemistry, 107: 332-341, 116.

[19] Morgan, K.C. (2010). What Are the Types of Soil in Freshwater Biomes? http://

[20] www.list_7471707_types-soil-freshwaterbiomes.html retrieved 11/6/2016

[21] Moore P.D., Jr. Daniel, T.C., Gilmour J.T., Shereve B.R., Edward D. R. and Wood, B.H. (1998) "Decreasing Metal Runoff from Poultry Litter with Aluminium Sulfate". Journal of Environmental Quality, 27: 92-99.

[22] Muller, B. A. (2001): Residential Water Source and the Risk of Childhood Brain Tumors. Environmental Health Perspective, 109(6).

[23] Norusis, M. (2006). SPSS 14.0 Guide to Data Analysis. Prentice Hall; software edition.

[24] Nwachukwu, C. I. and Otokunefor, T. V. (2006). Bacteriological quality of drinking water supplies in the University of Port Harcourt, Nigeria. NigerianJournal of Microbiology, 20(3):1383-1388.

[25] Olaitan, S. O. and Lombin, C. (1984). Introduction to Tropical Soil Science. Editor ; Onazi, O. C. Macmillian Publisher Ltd, London. pp. 18-19.

[26] Olayemi, A.B. (1990). Some Microbiological Aspects of Pollution of Asa River, Ilorin, Nigeria. Ph.D. Thesis (University of Ilorin, Ilorin, Nigeria). pp. 159. 
[27] Onions, A.H. S., Allsopp, D. and Eggins,H.O.W. (1981). Smith's Introduction to Industrial Mycology. Seventh Edition. Edward Arnold, London.pp. 398.

[28] Pramer, D. E. and Schmidt, J. (1984). Experimental Soil Microbiology. Burges Publication Company, Minneapolis. pp. 11-15.

[29] Raveral, O., Cenci, R., Beone, G. M., Dantas, M. and Lodigiani, P. (2003). Trace element concentrations in freshwater mussels and macrophytesas related to those in their environment. Journal of Limnology, 62(1): 6170.

[30] Robert, E. R. and Stanley, M. A. (2000). Microbial Sediments. Second Edition. McGraw-Hill, New York. pp. 65-87.

[31] Saravanakumar, A., Rajkumar, M., Sesh, J. and Thivakaran, G. A. (2008). Seasonal variations in physic-chemical characteristics of water, sediment and soil texture in arid zone mangrove of KachchhGujarat. Journal Environmental Biology, 29: 725-732.

[32] Tamaki, H., Sekiguchi, Y., Hanada, S., Nakamura, K. Nomura, N.,Matsumura, M. and Kamagata, Y. (2005). Comparative analysis of Bacterial Diversity in Freshwater Sediment of a Shallow Eutrophic Lake by Molecular and Improved Cultivation-Based Techniques. Applied Environmental Microbiology,71(4): 2162-2169.

[33] Tukura, B. W., Kabgu, J. A., and Gimba, C. E. (2005). Bioaccumulation of trace metals in fish from Ahmadu Bello University Dam, Zaria, Nigeria. Nigeria Journal of Science Reservoir, 5: 91-95. 